Togun et al., Afr J Tradit Complement Altern Med., (2017) 14 (1): 110-122

doi:10.21010/ajtcam.v14i1.12

\title{
ISOLATION, CHARACTERIZATION AND IMMUNOCHEMICAL STUDIES ON FIBROUS \\ PROTEINS FROM COWRY SHELL (CYPRAEA MONETA, LINNAEUS)
}

\section{${ }^{1}$ R.A.Togun, ${ }^{1}$ R. O. Balogun, ${ }^{2}$ D.O. Adeyemi ${ }^{3}$ T.A. Esan, ${ }^{4}$ G.M Oyatogun., ${ }^{5}$ E.O Oziegbe, ${ }^{6}$ R. E. Okonji, ${ }^{6}$ A. Kuku}

${ }^{1}$ Department of Haematology and Immunology, Faculty of Basic Medical Sciences, Obafemi Awolowo University, Ile-Ife, Nigeria. ${ }^{2}$ Department of Anatomy and Cell Biology, Obafemi Awolowo University, Ile-Ife, Nigeria. ${ }^{3}$ Department of Restorative Dentistry, Obafemi Awolowo University, Ile-Ife, Nigeria. ${ }^{4}$ Department of Material Sciences and Engineering, Obafemi Awolowo University, Ile-Ife Nigeria. ${ }^{5}$ Department of Child Dental Health, ObafemiAwolowo University, Ile-Ife, Nigeria. ${ }^{6}$ Department of Biochemistry, ObafemiAwolowo University, Ile-Ife, Nigeria.

+ Corresponding Author Email: thogun@yahoo.com

\begin{abstract}
Background: Biomaterials are non-drug substances used to treat, enhance or replace functions of body tissues or organs. Natural sources of biomaterials have recently become the focus of several research activities. Cowry shell constitutes one of the most promising natural sources of biomaterials because of its chemical stability, biodegradability and biocompatibility in the body. However, its applications may be limited due to immunogenic and toxic responses that may occur following implantation, hence this study.

Materials and Methods: Crude fibrous protein extracted with citrate buffer from pulverised cowry shells (Cypraea moneta (L)), was resolved into two components (CSP1 and CSP2) by gel filtration. Immunological studies were performed with antisera obtained from rabbits by double immunodiffusion and immunoelectrophoresis techniques. Mice treated with the proteins were observed for signs of toxicity and their liver, kidney, lungs and spleen were processed histologically.

Results: The native molecular weight of CSP1 and CSP2 determined by gel filtration were $91 \mathrm{kDa}$ and $33 \mathrm{kDa}$ respectively. CSP1 and CSP2 displayed single bands on SDS-PAGE with subunit molecular weight values of 19kDa and $19.5 \mathrm{kDa}$ respectively. Antisera obtained from rabbits immunised with the crude citrate buffer extracts precipitated the antigen in double immunodiffusion tests. Histopathological examinations revealed a dose-dependent damaging effect of the shell proteins on liver, kidney, lung and spleen tissues of the treated mice.

Conclusion: This study showed that cowry shells contain fibrous proteins which are immunogenic and toxic in mice at relatively high concentrations, causing visible organ damage without concurrent physical manifestations.
\end{abstract}

Key words: cowry shell protein, purification, immune activation, toxicity.

\section{Introduction}

Cowry shells constitute one of the most promising natural products suitable for use as natural biomaterials, while biomaterials are defined as non-drug substances suitable for inclusion in systems, which augment or replace the function of bodily tissues or organs (Ige et al., 2012).Cowry shells are also one of the most abundant natural sources of chitin and its derivative, chitosan, which have great biological potentials for a wide range of applications such as in the food and medical fields (Lim et al., 2010; Li et al., 2010) agriculture (Kulikov et al., 2006), aquaculture (Rajesh et al., 2008), dental (Arnaud et al., 2010) and membranes (Kim et al., 2007). Three main areas of applications of natural products as biomaterials in medicine include; wound management products, drug delivery systems, and tissue engineering (Ige et al., 2012). By virtue of their use as biomaterials, cowry shell products, with their reported protein content, are also potential activators of immune responses or carriers of toxic effects in living bodies. An understanding of the nature, biochemical and immunochemical characteristics of the proteins in cowry shell is essential for the promotion of its use as biomaterials in biomedical procedure and research. Hence, this study is designed to investigate the proteins of cowry shells and their toxicological effects in mice and to explore the possible immunological consequences of the use of cowry shell products as biomaterials. 
Togun et al., Afr J Tradit Complement Altern Med., (2017) 14 (1): 110-122

doi:10.21010/ajtcam.v14i1.12

\author{
Materials and Methods \\ Identification of cowry shell
}

Cowry shells purchased from a local market in Ile-Ife were identified by a taxonomist in the Department of Zoology, Obafemi Awolowo University, Ile-Ife, Nigeria.

Preparation of cowry shell powder:

Cowry shells were thoroughly washed with distilled water to remove dust and insect larvae. The samples were broken into small pieces, sundried and pulverised with an electric blender.

\title{
Proximate analysis of cowry shell
}

Proximate analysis of Cowry shell powder was carried out in the Department of Animal Science, Obafemi Awolowo University, Ile-Ife using the procedure of the Association of Official Analytical Chemistry (A.O.A.C., 2006).

\section{Extraction of cowry shell proteins}

Nine grams of cowry shell powder was extracted using two methods; globular protein extraction with phosphate buffered saline (PBS) (0.15 M, pH 7.2) and the fibrous protein extraction method with $0.1 \mathrm{M}$ citrate buffer (pH 2.65) (Baden et al., 1976). Prior to extraction, the shell powder was defatted twice by gently stirring with petroleum spirit for 15 minutes at room temperature, using $50 \mathrm{ml}$ of petroleum ether to $5 \mathrm{~g}$ of shell powder before the powder was dried at room temperature. The dried defatted powder was suspended each in 5 volume of the buffers. The mixture was homogenized using mortar and pestle, stirred for 1 hour and incubated at $4^{0} \mathrm{C}$ for $24 \mathrm{hrs}$ with intermittent stirring. The suspension was centrifuged at 4,000 rpm for 20 minutes and the protein concentration was routinely determined by the Bradford method (Bradford, 1976).

\section{Gel filtration chromatography of cowry shell crude extracts on sephadex G-150}

Crude PBS- or citrate buffer extract $(5 \mathrm{mg} / \mathrm{ml}, 6 \mathrm{ml})$ was layered on a column $(2.5 \times 45 \mathrm{~cm})$ of sephadex G150 , equilibrated with PBS or $0.1 \mathrm{M}$ citrate buffer ( $\mathrm{pH} 2.65$ ). Fractions of $3 \mathrm{ml}$ were collected at a flow rate of 20 $\mathrm{ml} / \mathrm{hr}$. Protein was monitored spectrophotometrically at $280 \mathrm{~nm}$ and each protein peak was pooled separately.

\section{Determination of apparent molecular weight}

Two peaks termed cowry shell protein (CSP) 1 and 2, were pooled from citrate buffer chromatography and concentrated by freeze drying. The native molecular weight of CSP1 and CSP2 were determined on a sephadex G150 column $(2.5 \times 45 \mathrm{~cm})(\mathrm{Vo}, 53 \mathrm{ml} ; \mathrm{Vt}, 221 \mathrm{ml})$. The standard proteins were ovalbumin $\left(\mathrm{M}_{\mathrm{r}} 45,000 ; 5 \mathrm{mg} / \mathrm{ml}\right)$, bovine serum albumin $\left(\mathrm{M}_{\mathrm{r}} 67,000 ; 5 \mathrm{mg} / \mathrm{ml}\right)$, creatinine phosphokinase $\left(\mathrm{M}_{\mathrm{r}} 88,000 ; 5 \mathrm{mg} / \mathrm{ml}\right)$, and $\gamma$-globulin $\left(\mathrm{M}_{\mathrm{r}}\right.$ 150,$000 ; 5 \mathrm{mg} / \mathrm{ml}$ ). Total sample volume of each of the protein markers and purified sample applied to the column was $5 \mathrm{ml}$. They were eluted at a flow rate of $10 \mathrm{ml}$ per hour. Fractions of $3 \mathrm{ml}$ were collected and monitored by measuring the absorbance at $280 \mathrm{~nm}$.

\section{Non-SDS and SDS polyacrylamide gel electrophoresis}

Non-sodium-dodecyl-sulphate (SDS) and SDS polyacrylamide gel electrophoresis (PAGE) were performed on the crude extract and the purified fractions of cowry shell proteins respectively, for the purpose of ascertaining purity of chromatography fractions, and for the determination of subunit molecular weights. The subunit molecular weight of the two proteins were determined by SDS-PAGE on 10\% rod gels, under reducing conditions using the phosphate buffer system according to standard procedure (Weber and Osborn, 1975). Molecular weight marker range 14,000-70,000) obtained from Sigma molecular weight markers calibration kit for SDS-PAGE was used to calibrate the gels. 


\section{Togun et al., Afr J Tradit Complement Altern Med., (2017) 14 (1): 110-122 doi:10.21010/ajtcam.v14i1.12}

\section{Immunological studies}

Rabbits were immunized with crude PBS- or citrate buffer extracts of cowry shell proteins according to the method of Traniello et al. (1975). The rabbits were obtained from the Animal Houseof the College of Health Sciences of Obafemi Awolowo University, Ile-Ife. The crude extract $(0.3 \mathrm{ml})$ was emulsified with an equal volume of Freunds' adjuvant. A portion of the resulting emulsion was injected subcutaneously and the other portion was injected intramuscularly into the thigh of rabbits. The injections were repeated 12 days later. Blood was collected from the ear vein 45 days after the first injection and serum was obtained from the clotted blood at room temperature. The serum was stored frozen at $-20^{\circ} \mathrm{C}$ until required.

\section{Ouchterlony double immunodiffusion test in agar gel}

Agarose solution (1.0\%) was prepared in $0.02 \mathrm{M}$ Sodium barbitone buffer ( $\mathrm{pH} 7.2$ ) containing $0.02 \%$ sodium azide. The agar was poured onto a clean slide and allowed to set. One central well and four surrounding wells were cut in the agar using the appropriate gel cutter. After the agarose plugs had been removed, the central well was filled with $5 \mu \mathrm{l}$ rabbit anti- crude CSP serum obtained after 45 days immunization protocol. $5 \mu 1$ of CSP was delivered into the surrounding wells. The slides were incubated overnight in a humid chamber at room temperature and examined for immunoprecipitation.

\section{Immunoelectrophoresis}

One percent agarose solution was prepared in $0.02 \mathrm{M}$ barbitone buffer $(\mathrm{pH} 7.2)$ containing $0.02 \%$ sodium azide. The agarose $(20 \mathrm{ml})$ was poured onto 2.5 by $7.5 \mathrm{~cm}$ slides and allowed to set. Two wells at both sides of a middle trough were cut on the gel, using the appropriate gel cutter. After the agarose plugs had been removed, the wells were filled with $5 \mu \mathrm{l}$ of cowry shell crude extract to which a small amount of bromophenol blue dye had been added as a marker. The slide was placed on the electrophoresis apparatus, and connected with rayon or filter paper wicks to the buffer chambers filled with $0.02 \mathrm{M}$ barbitone buffer ( $\mathrm{pH} 7.2$ ). A current of $8 \mathrm{~mA}$ per slide was applied, such that the voltage drop across the slide was $35 \mathrm{~V}$. At the end of the electrophoresis, the trough was filled with 75 $\mu l$ of cowry shell crude extract antiserum serum after the agarose plug had been removed. The slide was incubated overnight in a humid chamber and examined for precipitation.

\section{Toxicity Study}

Twenty-four Healthy inbred mice (Mus musculus) $(14-18 \mathrm{~g})$ of both sexes were used for the experiment. They were maintained under standard environmental conditions of temperature, humidity and light and fed on standard rat pellets (Ladokun feeds, Ibadan, Nigeria) and water ad libitum. The mice were acclimatized to the laboratory environment for two weeks before the administration of the test material. The mice received humane care according to the criteria outlined in the "Guide for the Care and Use of Laboratory Animals" as approved by the Institute of Laboratory Animal Research of the USA National Research Council (National Research Council, 1996) and their experimental use was approved by the Animal Ethics Committee of Obafemi Awolowo University, Ile Ife. The animals were divided into four groups of six mice each. Group A was the control, group B, C and D were the test groups. The animals in test groups received single dose (i.p.) of the cowry shell protein (CSP) constituted in citrate buffer solution, in concentrations of 10,100 , and $1000(\mathrm{mg} / \mathrm{kg} \mathrm{bw})$ while control group was received citrate buffer solution only. The body weight, packed cell volume (PCV) and white blood cell (WBC) counts of the mice were determined before and after administration of the test material. The mice were observed for $72 \mathrm{hr}$. At the end of the 15-day experimental period, the mice were sacrificed under chloroform anaesthesia.

\section{Determination of PCV and WBC Counts}

Blood samples were collected into heparinised capillary tubes (BDH, UK) and the PCV was determined by micro haematocrit technique. The samples were centrifuged for 5 min at 12,000 rpm after which the PCV was read with the haematocrit reader. White blood cells were counted using improved Neubeur haematocytometer. 
Togun et al., Afr J Tradit Complement Altern Med., (2017) 14 (1): 110-122

doi:10.21010/ajtcam.v14i1.12

\section{Histology}

The animals were sacrificed under chloroform anaesthesia and the kidneys, lungs, liver, and spleen of each of the animals were excised and fixed in $10 \%$ buffered formalin. The tissues were processed via paraffin wax embedding method of Drury and Wallington (1980). Sections of $6 \mu \mathrm{m}$ thickness were produced on a rotary microtome and stained with hematoxylin and eosin ( $\mathrm{H}$ and $\mathrm{E})$ stain for general histological assessment. The sections were examined under a Leica DM 750 research microscope with a digital camera (Leica ICC 50) attached. Digital photomicrographs of the sections were taken at various magnifications.

\section{Statistical Analysis}

All values were presented as mean \pm standard error of mean (SEM). The significance of difference in the means of all parameters before and after the treatments was determined using students' $\mathrm{T}$ test. Values of $\mathrm{p}<0.05$ were considered as significant.

\section{Results \\ Proximate Analysis}

Table 1 shows the percentage dry weight proximate composition of cowry shells (Cypraea moneta). The proximate analysis of powdered cowry shell showed a very high content of ash, representing almost about $90 \%$ of the total dry weig

Table 1: Proximate Composition of Cowry shell (Cyprea moneta) (\% dry weight)

\begin{tabular}{ll} 
Moisture content & 0.74 \\
Crude fibre & 4.38 \\
Crude protein & 1.91 \\
Nitrogen content & 0.30 \\
Ash content & 88.82 \\
Crude fat & 0.18 \\
Carbohydrate & 4.22 \\
\hline
\end{tabular}

Proximate analysis of Cyprea moneta shell according to the method of the association of official analytical chemistry [8]

\section{Purification of protein}

The concentration of crude PBS - extracts of cowry shell was $0.51 \mathrm{mg} / \mathrm{ml}$ per $9 \mathrm{~g}$ of powdered cowry shell, while that of the fibrous protein in citrate buffer was $185 \mathrm{mg} / \mathrm{ml}$ per $9 \mathrm{~g}$ of powdered cowry shell under similar extraction conditions. The elution profile of PBS-extract of cowry shell protein by gel filtration on Sephadex G-150 is shown in Figure 1. The protein peaks were unresolved and not well defined; therefore, no protein peak was pooled. Hence no further analysis was done using PBS-extracts of cowry shells except in immunological studies. Figure 2 shows the elution profile of the citrate buffer extract of cowry shell by gel filtration $n$ chromatography on sephadex G-150. Eluant was $0.1 \mathrm{M}$ citrate buffer, $\mathrm{pH}$ 2.65. The elution profile showed two highly resolved protein peaks labelled as CSP1 and CSP2 consecutively. Native molecular weight of CSP1 and CSP2 were determined by gel filtration on Sephadex G-150. The molecular weight for CSP1 was approximately 91,000 Da and for CSP2, 33,000 Da (Fig 3). Subunit molecular weights of the two proteins were determined using SDS-PAGE Both CSP1 and CSP2 were run separately on SDS-PAGE and showed only one band each (Fig 4). 
Togun et al., Afr J Tradit Complement Altern Med., (2017) 14 (1): 110-122

doi:10.21010/ajtcam.v14i1.12

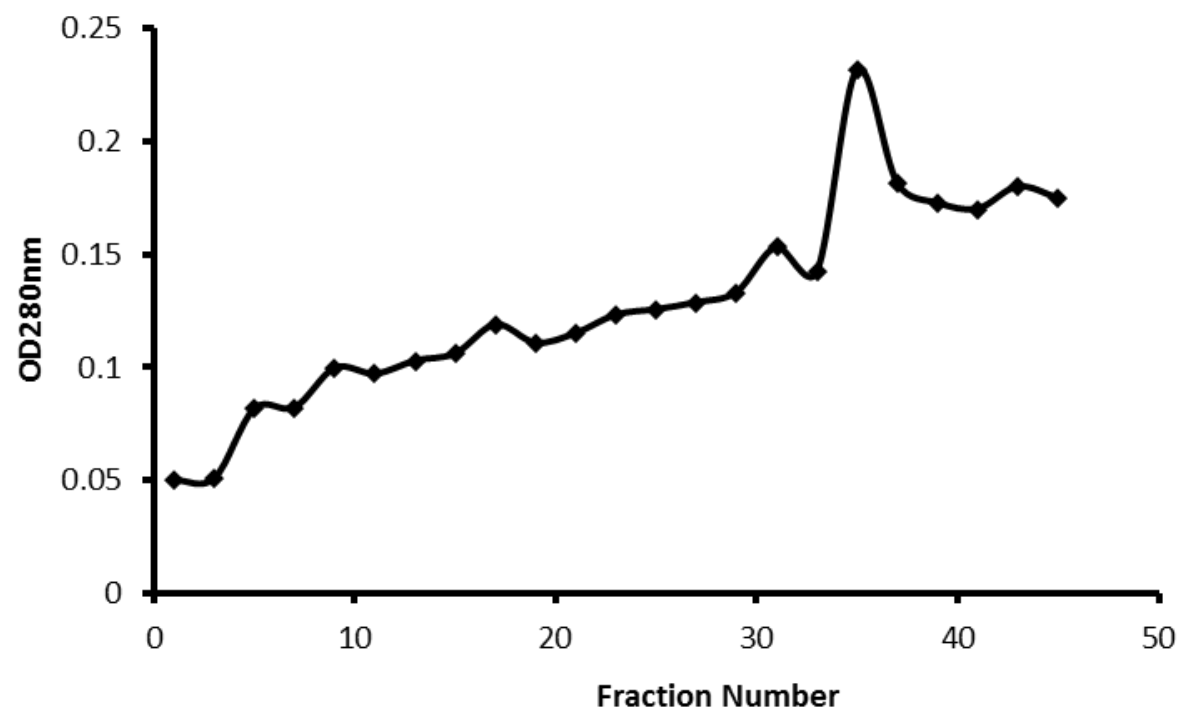

Figure 1: Sephadex G-150 gel filtration chromatography of PBS-crude extract of cowry shell powder. The column was first equilibrated with $500 \mathrm{ml} 0.1 \mathrm{M}$ Phosphate buffered saline (PBS), pH 7.2 for $24 \mathrm{hrs}$. Column size: $2.5 \times 45 \mathrm{~cm}$., Volume layered: $6 \mathrm{ml}$., Flow rate: $20 \mathrm{ml} / \mathrm{hr}$., Fraction volume: $3 \mathrm{ml}$

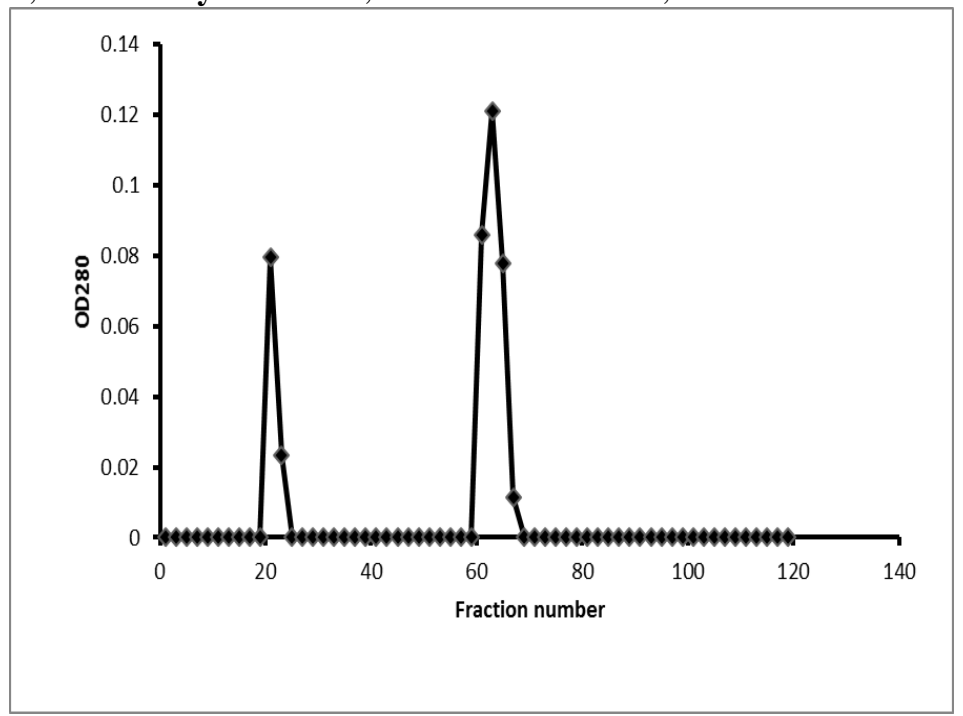

Figure 2: Sephadex G-150 Gel Filtration Chromatography of Citrate Buffer- Crude Extract of Cowry Shell Powder. The column was first equilibrated with $500 \mathrm{ml} 0.1 \mathrm{M}$ Citrate Buffer, $\mathrm{pH} 2.65$ for $24 \mathrm{hrs}$.

A- CSP 1., CSP 2., Column size: $2.5 \times 45 \mathrm{~cm}$., Volume layered: $6 \mathrm{ml}$., Flow rate: $20 \mathrm{ml} / \mathrm{hr}$., Fraction volume: $3 \mathrm{ml}$ 
Togun et al., Afr J Tradit Complement Altern Med., (2017) 14 (1): 110-122

doi:10.21010/ajtcam.v14i1.12

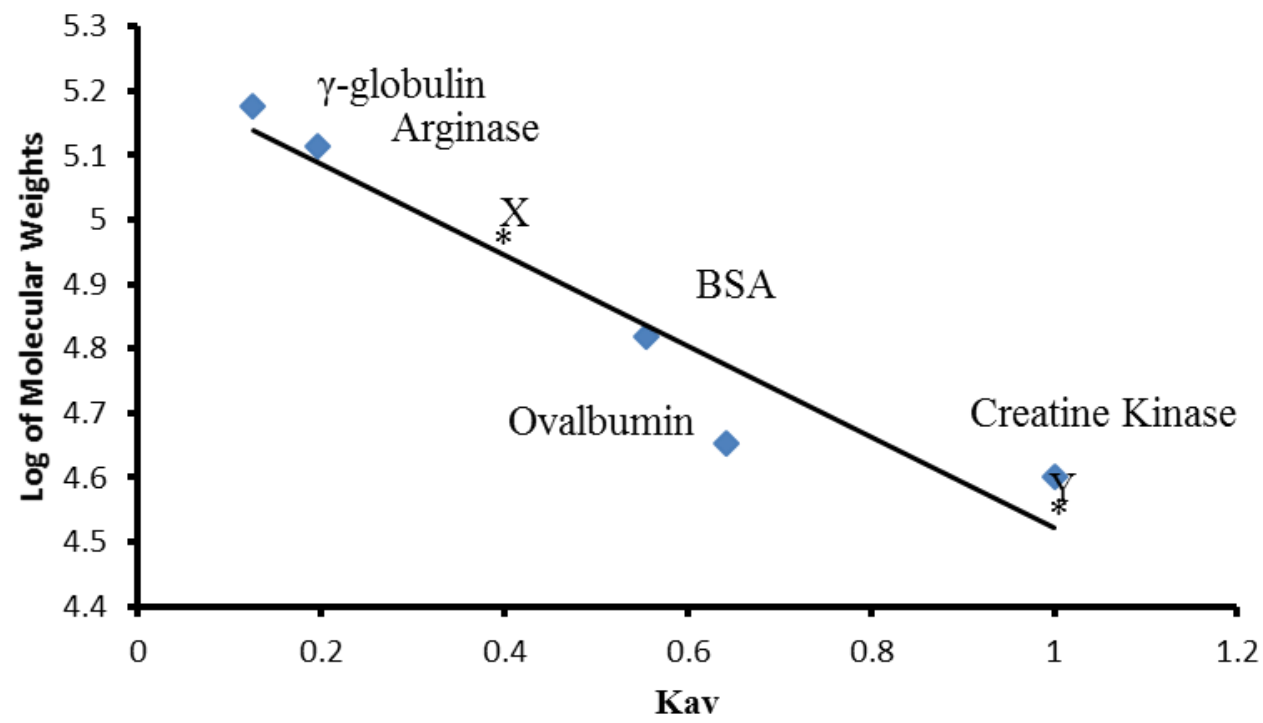

Figure 3: Molecular weight determination by gel filtration chromatography on Sephadex G-150.

The standard proteins as indicated on the curve are Creatine Kinase, 40,000; ovalbumin, 45,000; bovine serum albumin (BSA), 66,000; Arginase, 130,000; $\gamma$-globulin 150,000. CSP1 and CSP2 were indicated by X and Y, which corresponded to molecular weights $91 \mathrm{kDa}$ and $33 \mathrm{kDa}$ respectively.

Column size: $2.5 \times 45 \mathrm{~cm}$. Void volume $\left(\mathbf{V}_{\mathbf{o}}\right)=53 \mathrm{ml}$, Total volume eluted $\left(\mathbf{V}_{\mathfrak{t}}\right)=(221 \mathrm{ml})$, Flow rate: $20 \mathrm{ml} / \mathrm{hr}$, Fraction volume: $3 \mathrm{ml}$

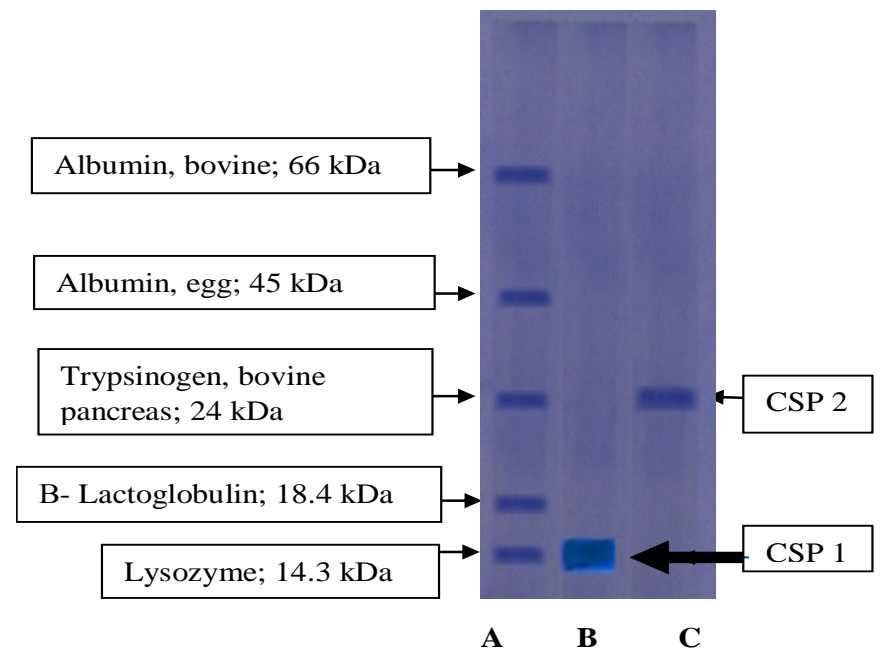

The standard proteins (Sigma Molecular Weight Markers Calibration Kit) consisted of Ovalbumin, 45,000, Trypsinogen, 24,000, $\beta$-Lactoglobulin, 18,400, and Lysozyme, 14,300 .
A- Standard protein markers
B- CSP 1
C- CSP 2

Figure 4: $10 \%$ SDS-PAGE showing standard protein markers and the purified cowry shell proteins ( CSP1 and CSP2) 
Togun et al., Afr J Tradit Complement Altern Med., (2017) 14 (1): 110-122

doi:10.21010/ajtcam.v14i1.12

\section{Immunological Studies}

The reactivity of the antiserum against the protein antigens was tested using the Ouchterlony double immunodiffusion technique and immunoelectrophoresis. There was no visible precipitin line observed when PBSextract of cowry shell was reacted with its corresponding antiserum in Ouchterlony agarose gels. However, citrate buffer crude extracts of cowry shells formed clear precipitin lines on reaction with the corresponding antiserum in Ouchterlony plates (Fig 5), and also formed clear precipitin lines in immunoelecrophoresis experiments (Fig 6).

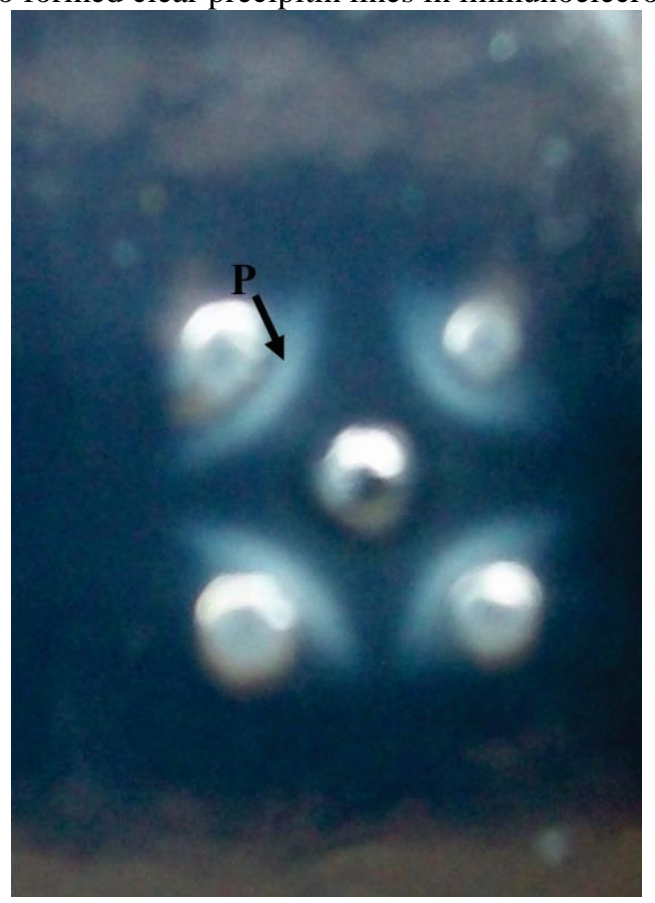

Figure 5: Plate showing precipitin line (P) on Ouchterlony (Double immuodiffusion) test. Immunoprecipitation of CSP1 and CSP2. The central well contained rabbit anti-cowry shell protein serum containing cowry shell protein antibody. The surrounding wells contained the citrate buffer crude extract.

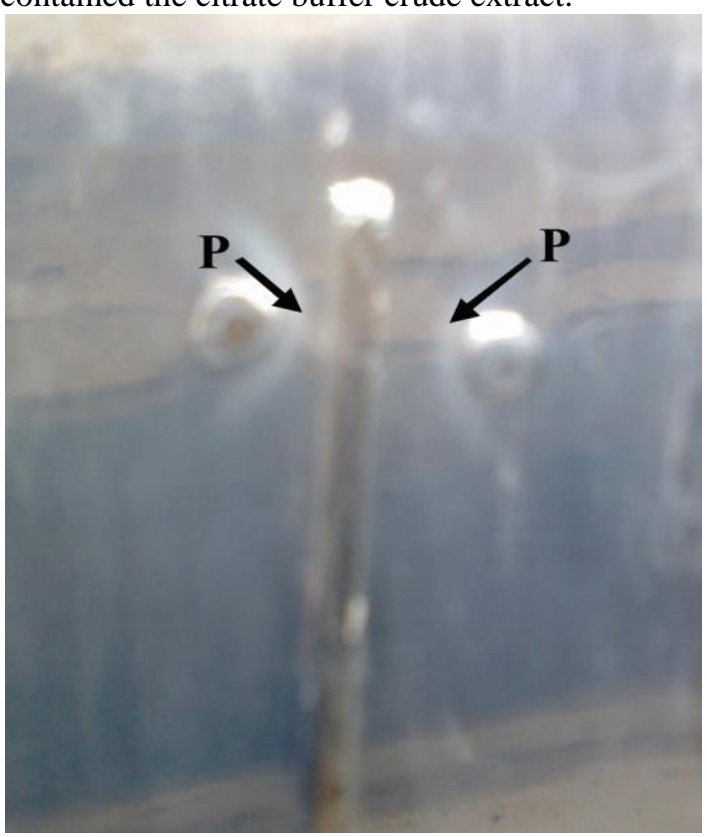

Figure 6: Plate showing precipitin (P) arcs on Immunoelectrophoresis. 


\section{Togun et al., Afr J Tradit Complement Altern Med., (2017) 14 (1): 110-122 doi:10.21010/ajtcam.v14i1.12}

Crude citrate buffer extract of cowry shell was subjected to electrophoresis, and then precipitated by antibodies placed in the trough after immunodiffusion occurred over 24 hours.

\section{Toxicity Study}

There was no mortality recorded from daily observations of all treated and control mice throughout the experimental period. The mean body weight, PCV and WBC counts in groups A, C and B of mice before and after treatment are presented in Tables 2, 3 and 4. There were no significant differences between the mean body weight of control (group A) and treated groups of mice (C and D) before and after treatment with cowry shell proteins. However, the mean body weight of group B mice was significantly higher after treatment than before $(\mathrm{p}<0.05)$ (Table 2), for no apparent reasons. Table 3 shows the mean PCV of each group of mice before and after treatment of the animals. There was no significant difference in the two PCVs. Similarly, WBC counts of mice within each treatment group did not show any significant difference before or after treatment (Table 4).

Table 2: Mean body weight ( $\mathrm{g}$ ) of mice before and after treatment

\begin{tabular}{|c|c|c|c|c|}
\hline & Group A & Group B & Group C & Group D \\
\hline $\begin{array}{l}\text { Weight before } \\
\text { treatment }(\mathrm{g})\end{array}$ & $27.13 \pm 0.81$ & $27.17 \pm 1.01$ & $29.23 \pm 1.32$ & $31.73 \pm 3.42$ \\
\hline $\begin{array}{l}\text { Weight after } \\
\text { treatment }(\mathrm{g})\end{array}$ & $28.86 \pm 1.61$ & $29.29 \pm 0.83 *$ & $30.71 \pm 3.32$ & $33.26 \pm 2.04$ \\
\hline
\end{tabular}

Table 3: Mean PVC (\%) of mice before and after treatment

\begin{tabular}{lcccc}
\hline & Group A & Group B & Group C & Group D \\
\hline PCV before treatment $(\%)$ & $48.67 \pm 2.31$ & $50.16 \pm 2.65$ & $45.27 \pm 4.36$ & $44.03 \pm 4.58$ \\
PCV after treatment $(\%)$ & $52.11 \pm 2.64$ & $52.33 \pm 2.51$ & $49.67 \pm 4.51$ & $46.33 \pm 3.21$ \\
\hline
\end{tabular}

Table 4: Mean WBC counts $(/ \mu \mathrm{L})$ of the mice before and after treatment

\begin{tabular}{lcccc}
\hline & Group A & Group B & Group C & Group D \\
\hline $\begin{array}{l}\text { WBC counts } \\
\text { before } \\
\text { treatment }(/ \mu \mathrm{L})\end{array}$ & $8.57 \times 10^{3} \pm 7.11 \times 10^{2}$ & $1.07 \times 10^{4} \pm 8.98 \times 10^{2}$ & $8.90 \times 10^{3} \pm 7.68 \times 10^{2}$ & $9.13 \times 10^{3} \pm 8.31 \times 10^{2}$ \\
$\begin{array}{l}\text { WBC counts } \\
\text { after treatment } \\
(/ \mu \mathrm{L})\end{array}$ & $9.03 \times 10^{3} \pm 7.66 \times 10^{2}$ & $1.19 \times 10^{4} \pm 8.64 \times 10^{2}$ & $9.02 \times 10^{3} \pm 6.72 \times 10^{2}$ & $9.53 \times 10^{3} \pm 8.03 \times 10^{2}$ \\
\hline
\end{tabular}

\section{Histopathological studies}

Histopathological studies on the effects of CSP administration on the liver, kidney, lung and spleen of the mice indicated progressive organ damage commensurate with dose of antigen.Examination of the liver sections showed that cowry shell protein had a dose dependent hepatotoxicity effect in mice. At the least dose of $10 \mathrm{mg} / \mathrm{kg}$ body weight there was no appreciable changes in the liver architecture, but at higher dosage there were damages to the liver (Fig. 7). Vacuolation and degenerative ballooning of the hepatocytes, distorted and irregular sinusoids as well as dilatation of the bile canaliculi were observed in the liver of mice treated with higher doses of CSP (Fig. 7).

The kidney morphology revealed a dose-dependent renal damage marked by necrosis and fatty accumulations in the glomerulus of the kidney of mice treated with higher doses of CSP (>100 mg/kg body weight) (Fig. 8).

A dose-dependent reduction in the respiratory portion of the lungs marked by different degrees of alveolar wall thickening and air space cellularity was observed on examination of $\mathrm{H} \& \mathrm{E}$ stained sections of the lungs of the 
Togun et al., Afr J Tradit Complement Altern Med., (2017) 14 (1): 110-122

doi:10.21010/ajtcam.v14i1.12

treated mice (Fig. 9). Splenic morphology of treated mice showed reactive splenic follicles with increased lymphopoiesis. However splenic follicles of the control mice were in the resting state (Fig. 10).

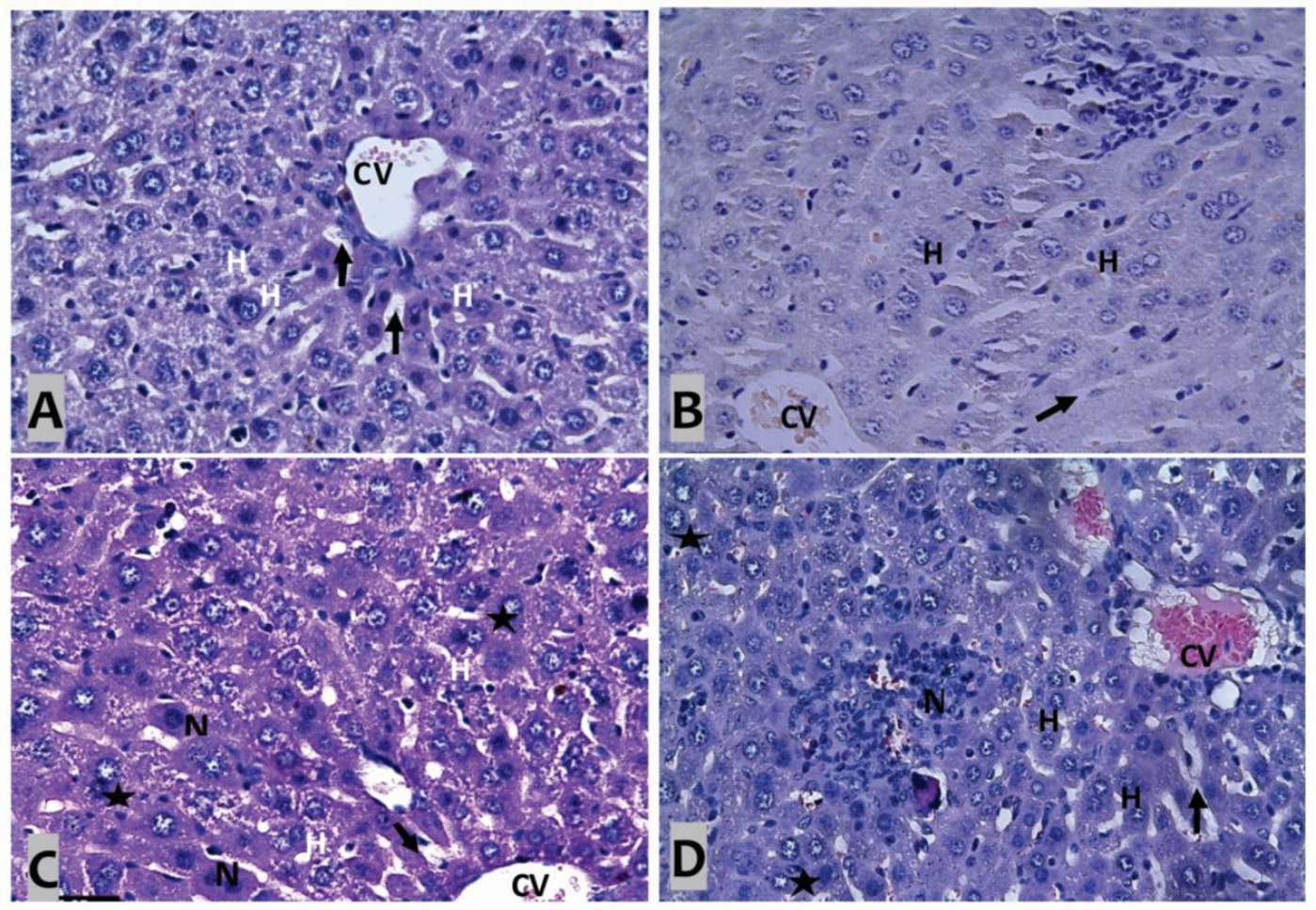

Figure 7: Photomicrographs showing the liver of the control and treated mice.

Photomicrographs showing the liver of the control and treated mice. (A is the control, B. C and $\mathrm{D}$ are liver sections of groups treated with 10,100 and $1000 \mathrm{mg} / \mathrm{kg}$ bw respectively). Note the hepatocytes $(\mathrm{H})$ were arranged in plates around the central vein $(\mathrm{CV})$ with sinusoids ( $\mathbf{v})$ in between the plates. Architecture of the control (A) liver appeared normal. Distortion of architecture and a dose-dependent necrosis $(\mathrm{N})$ and vacuolation $(\boldsymbol{\star})$ of the hepatocytes were observed in the liver of treated mice (B, C and D). Vascular congestion of the central vein was also observed in the liver of group D mice. (H \& E X 400)

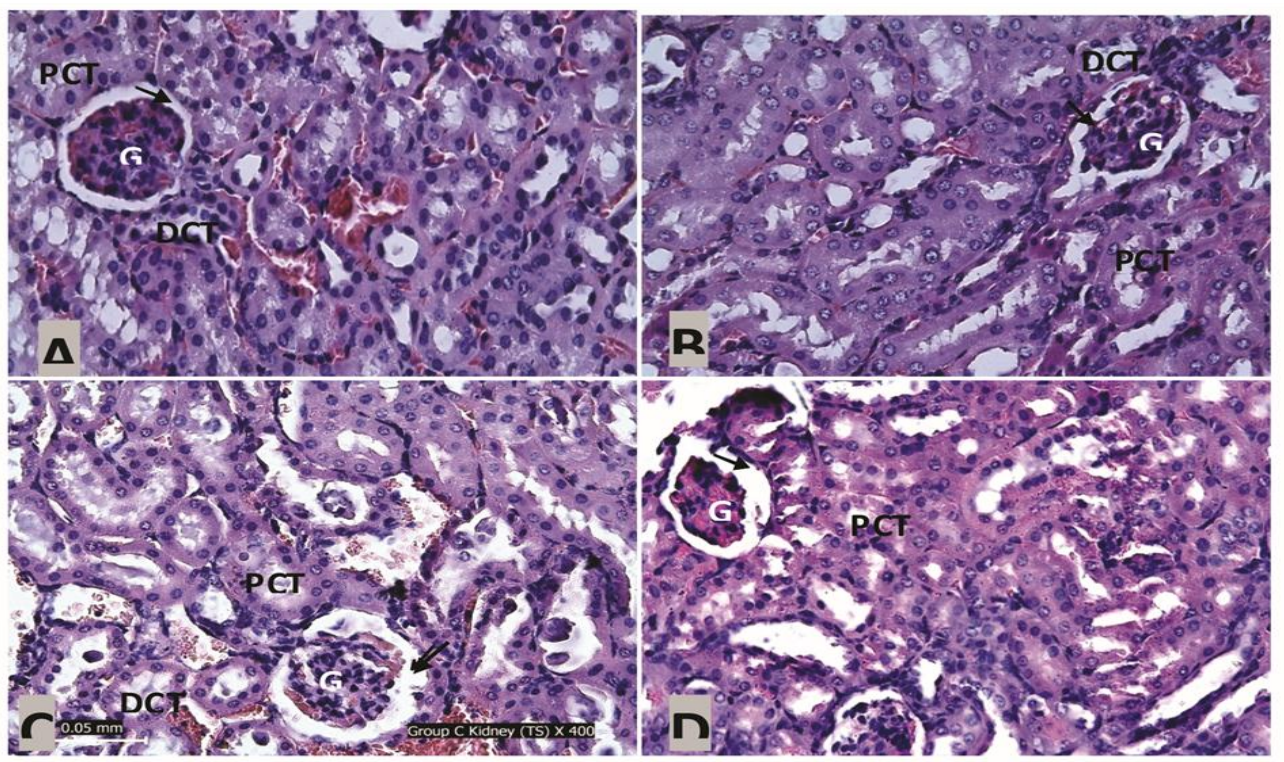




\section{Togun et al., Afr J Tradit Complement Altern Med., (2017) 14 (1): 110-122}

doi:10.21010/ajtcam.v14i1.12

Figure 8: Photomicrographs showing the kidney of the control and treated mice.

Photomicrographs showing the kidney of the control and treated mice. (A is the control, B C and D are kidney sections of groups treated with 10, 100 and $1000(\mathrm{mg} / \mathrm{kg} \mathrm{bw})$ respectively). Note the glomerulus (G), Bowman space (1), proximal convoluted tubule (PCT) and the distal convoluted tubule (DCT). Architecture of the groups A and B kidney appeared normal while necrosis, fatty accumulation and Bowman space enlargement (indicating a reduced glomerular size) were observed in the kidney sections of groups $\mathrm{C}$ and D mice. ( $\mathrm{H} \& \mathrm{E} \mathrm{X} 400$ )

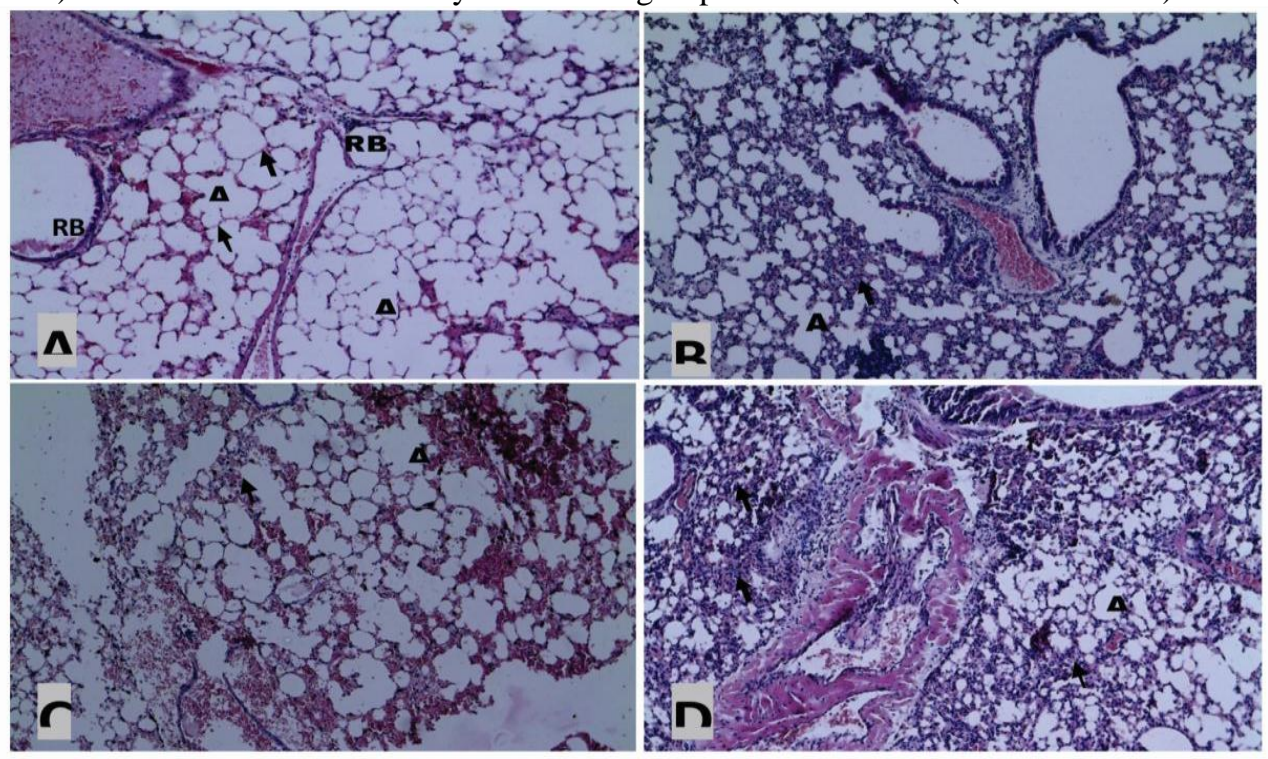

Figure 9: Photomicrographs showing the lungs of the control and treated mice.

Photomicrographs showing the lungs of the control and treated mice. (A is the Tontrol, B. C and D are lung sections of groups treated with 10,100 and $1000 \mathrm{mg} / \mathrm{kg}$ bw respectively). The lungs of the control mice had a normal spongy appearance due to the presence of numerous air-filled alveolar sacs (A) on the respiratory bronchioles (RB). The alveolar wall (1) was thin to allow gaseous exchange. The lungs of treated mice (B, C and D) showed a reduction in its respiratory portion due to thickening of the alveolar wall ( ) and inter-alveolar septum. This is an indication of pulmonary emphysema in the lungs of treated mice. (H \& E X 100)
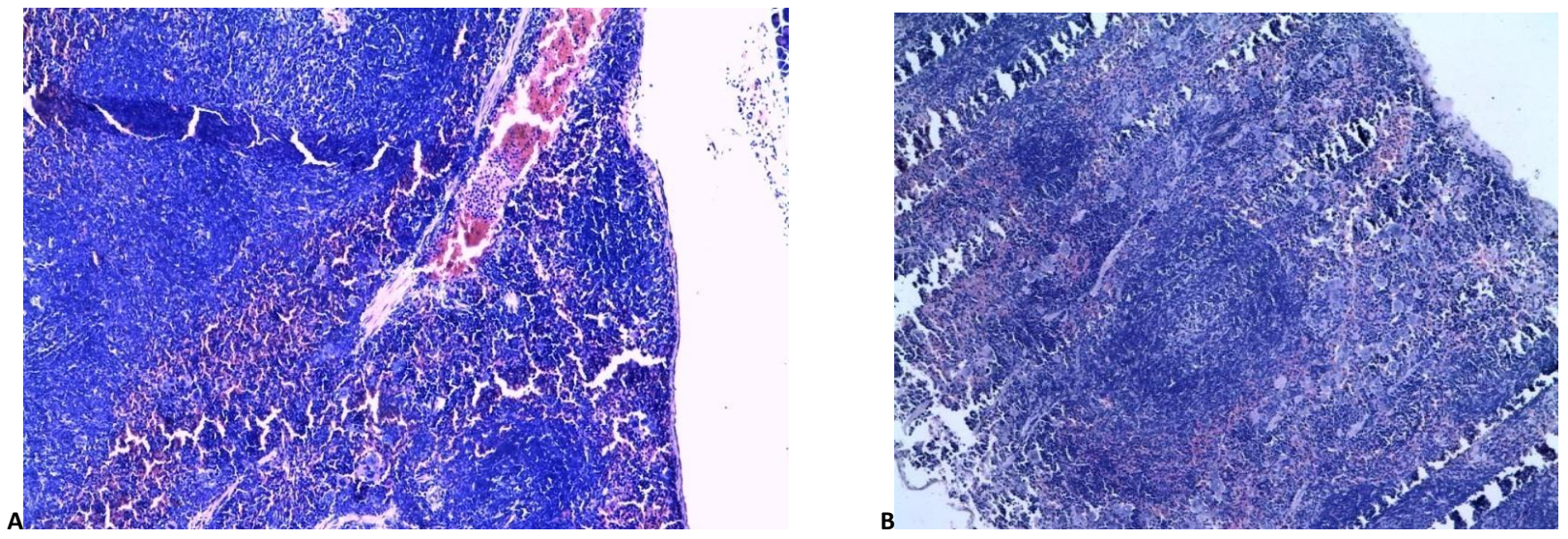
Togun et al., Afr J Tradit Complement Altern Med., (2017) 14 (1): 110-122 doi:10.21010/ajtcam.v14i1.12
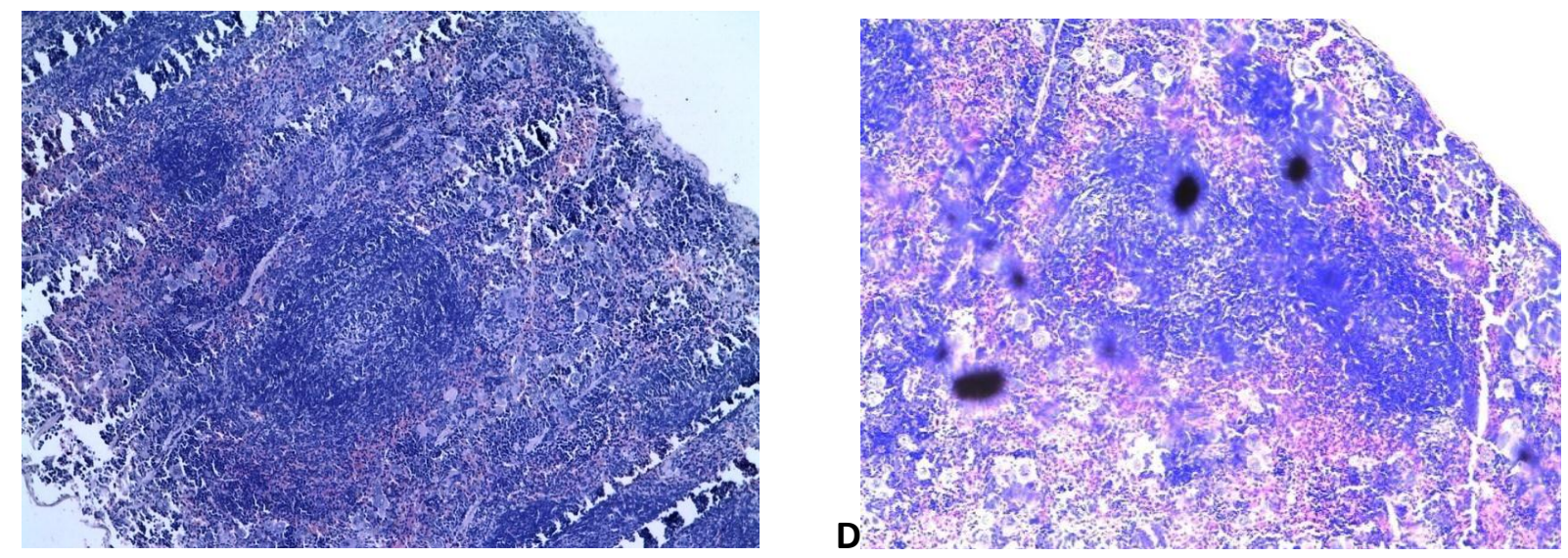

C

Figure 10: Photomicrographs showing the spleen of the control and treated mice

Photomicrographs of the spleen of the control (A) and treated mice (B, C, D) showing the white pulp (WP) (containing lymphoid nodules) and the red pulp (RP). A dose dependent decrease in the concentration of lymphoid follicles in the WP was observed in these sections. (H \& E X 100).

\section{Discussion}

The result obtained from the proximate analysis of powdered cowry shell is in agreement with the findings of previous researchers (Oloyede, 2008). The high ash content in cowry shell is due to the high content of calcium carbonate and inorganic components in the form of salts and oxides in the shell (Usman, 2006).The crude fibre content of $4.38 \%$ is also in agreement with those obtained for other species of snail shell Archatina archatina (4.06\%) and Limucalaria sp. (4.14\%) (Ihekoronye and Ngoddy, 1985), enhancing the toughness and hardness of the shell.The very low Nitrogen content $(0.30 \%)$ is indicative of the low protein content and agrees with those reported by Jurkiewicz-Karnkowska (2004), where the respective values of nitrogen in the shells of the investigated molluscs species were between 0.19 to $0.56 \%$ dry wt.

The yield of crude protein extracts from cowry shell with citrate-citric acid buffer ( $\mathrm{pH} 2.65$ ) was about 362 times higher than that obtained with PBS-extract under the same experimental conditions. The citrate buffer extract was clearly resolved into two peaks (termed CSP1 and CSP2) by gel filtration, whereas the proteins of PBS-extract were not resolvable by this method, hence could not be purified further. Furthermore, CSP1 and CSP2 proteins each showed clear single bands on SDS-PAGE indicating the presence of single protein specie.

Native molecular weights of CSP1 and CSP2 determined by gel filtration on Sephadex G-150 were $91 \mathrm{kDa}$ and $33 \mathrm{kDa}$ respectively. The $91 \mathrm{kDa}$ protein showed a single band of $19 \mathrm{kDa}$ on SDS-polyacrylamide gel electrophoresis (SDS-PAGE) in the presence of mercaptoethanol, implying that the native protein consisted of 5 subunits; whereas the $33 \mathrm{kDa}$ protein which migrated as a single band of $19.5 \mathrm{kDa}$ on SDS-PAGE, probably comprised of two polypeptide chains. The difference between the native molecular weight and the weight of the sum of the subunits may be attributed to non-covalently bound attachments, or some additional low molecular weight components in the crude structure. These molecular weights agree with those of some other shells published in literature. Weiner et al. (1976) showed that organic matrix of the shell of Scabrotrigonia thoracica, after decalcification, is almost totally soluble, whereas the organic matrix of Neotrigonia margaritacea shell is predominantly insoluble. Both of the trigoniacean organic matrices had high-molecular-weight fractions excluded on Sephadex G-100. S. thoracica had an additional low-molecular-weight component. Bowen and Tang (1996) showed that Nacreous conchiolin proteins separated by SDS-PAGE have molecular weight of 37,800Da, 23,200Da, and 19,600Da. Martin-Garcia et al. (2007) obtained several proteins from razor shells (Ensis arcuatus) with molecular weight range of 10-98KDa by SDS-PAGE.

The reactivity of cowry shell protein antiserum against the protein antigens was tested using the Ouchterlony Double Immunodiffusion Technique and Immunoelectrophoresis. There was no visible precipitin line observed when PBS- extract of cowry shell was reacted with its corresponding antiserum in Ouchterlony agarose gels, However, citrate buffer crude extracts of cowry shells formed clear precipitin lines on reaction with the corresponding antiserum in Ouchterlony plates, and also formed clear precipitin lines in immunoelecrophoresis 


\section{Togun et al., Afr J Tradit Complement Altern Med., (2017) 14 (1): 110-122 doi:10.21010/ajtcam.v14i1.12}

experiments. This indicates that the fibrous proteins were immunogenic and therefore responsible for the immunological activity of CSP antigens. The insolubility of the fibrous proteins also reflected in the immunoelectrophoresis of the extract, since precipitation of the proteins occurred at the point of antigen application because of restricted mobility of the sample under the electric field. Marin et al. (2005) also used a polyclonal antiserum raised against caspartin in an immunolocalization technique to localize protein and demonstrate the distribution of the proteins in the shell.

Toxicity studies showed that there was no mortality recorded from daily observations of all treated and control mice throughout the experimental period. These finding were in agreement with some aspects of the report of Singh et al. (2010) in their toxicity study of oral administration of conch shell (Terbinella pyrum), cowry shell (Cypraea moneta), pearl oyster shell (Pinctada margaritifera), coral root (Tubipora musica), and coral stem (Corallium rubrum) in mice. They found that the levels of haemoglobin and WBC counts were not significantly changed. They did not find any sign of haemopoetic, hepatic or renal toxicity in the control and drug-treated rats. In addition, they did not observe any gross pathological lesion in the liver, stomach and kidney. Our study also did not find any haemopoietic toxicity but showed hepatic, renal, pulmonary and splenic toxicity, which were not observed in the control group of the mice. The observed pathological lesions in the liver of mice treated with higher doses of CSP were suggestive of toxic hepatitis in the liver of these mice. In addition, necrosis and fatty accumulations in the glomerulus of the kidney of treated mice shows nephrotoxicity effect which could eventually lead to kidney failure in these mice. In the lungs, different degrees of alveolar wall thickening may have been caused by emphysema, edema, interstitial infiltration with neutrophils and macrophages, as well as air-space cellularity, exudation and hyaline membrane formation, thereby reducing the respiratory portion of the lungs. Splenic morphology of treated mice showed reactive splenic follicles, with increased lymphopoiesis. The apparent depopulation of these follicles may be related to the mobilization of the lymphocytes into the blood stream in response to the presence of the proteins. As there is proliferation of more reactive lymphoid follicles into the blood, the follicles become decreased.

\section{Conclusion}

The study concluded that cowry shells contain two types of proteins, depending on methods of extraction. The globular proteins did not show any evidence of immune activation or toxicity, while the fibrous proteins elicited an immune response, as well as toxic effects in mice. Cowry shell fibrous proteins caused visible dose-dependent damages in some organs without concurrent physical manifestations of ailment in the mice. The study has implications in the use of cowry shells as a natural source of biomaterials suitable for use in body tissue replacement. It is suggested that further studies on the development of biomaterials from cowry shells should include methods for removing or deactivating the protein components.

Conflict of interest: The authors declare that there are no conflicts of interests.

\section{Authors' contributions}

TRA; designed and supervised the research, drafted manuscript, corresponding author. BRO; executed the experiment, ADO; supervised the toxicological study, prepared and interpreted the histological micrographs, prepared manuscripts. ETA, OGM, and OEO; conceived the research idea and involved in the research design. ORE and KA; co-supervised some biochemical aspects of the experiment. All authors read and approved the final manuscript.

\section{References}

1. Arnaud, T., Neto, B., Diniz, F. Chitosan Effect on Dental Enamel De-remineralization: An in vitro Evaluation. Journal of Dentistry, 2010. 38:848-852.

2. Association of Official Analytical Chemist (A.O.A.C.). Official methods of Analysis, $18^{\text {th }}$ Edition. Washington DC, 2006.

3. Baden HP, Lee LD, Kubilus J. The Fibrous Proteins of Stratum Corneum. The Journal of Investigative Dermatology 1976, 67(5): 573-576.

4. Bowen CE, TangH. Conchiolin-protein in Aragonite shells of molluscs. Comparative Biochemistry and Physiology Part A: Physiology, 1996,115(4): 269-275.

5. Bradford MM.A rapid and sensitive method for the quantification of microgram quantities of protein, utilizing the principle of protein dye binding. Anal. Biochem. 1976, 72: 248-254. 


\section{Togun et al., Afr J Tradit Complement Altern Med., (2017) 14 (1): 110-122}

\section{doi:10.21010/ajtcam.v14i1.12}

6. Drury, R.A. and Wallington E.A. Carleton's Histology Technique. 4th Edn., Oxford University Press, New York, 1980.

7. Ige OO, Lasisi EU, Aribo S.: Natural Products: A minefield of Biomaterials. ISRN Materials Science; 2012, 2012: Article ID 983062, 20 pages.

8. Ihekoronye AI and Ngoddy PO. Integrated Food Science for the Tropics. First Edition. Macmillian Publishers, Ltd.: London, UK. 1985.

9. Jurkiewicz-Karnkowska E. Accumulation in Molluscs from the Zegrzyński Reservoir Ecosystem.Polish Journal of Environmental Studies 2004, 14 (2):173-177

10. Kim C, Choi Y, Lee S, Gin Y, Son Y. Development of chitosan dermal scaffold and its characterization. Key Eng. Mater.2007, 342:181-184.

11. Kulikov S, Chirkov S, Ilina A, Lopatin S, Varlamov V. Effect of the molecular weight of chitosan on its antiviral activity in plants. Appl. Biochem. Microbiol. 2006, 42:200-203.

12. Li Z, Yubao L, Yi Z, Lan W, Jansen J. In vitro and in vivo evaluation on the bioactivity of ZnO containing nanohydroxyapatite/chitosan cement. J. Biomed. Mater. Res. A.2010,93 (1): 269-279.

13. Lim C, Yaacob N, Ismail Z, Halim A. In vitro biocompatibility of chitosan porous skin regenerating templates (PSRTs) using primary human skin keratinocytes. Toxicol. in Vitro.2010,24:721-727.

14. Marin F, Amons R, Guichard N, Stigter M, Hecker A, Luquet G, Layrolle P, Alcaraz G, RiondetCand Westbroek P. Caspartin and Calprismin. Two Proteins of the Shell Calcitic Prisms of the Mediterranean Fan Mussel, Pinna nobilis. The Journal of Biological Chemistry, 2005, 280 (40): 33895-33908.

15. Martin-Garcia C, Carnes J, Blanco R, Maerinez-Alonso JC, Callejo-Melgosa A, Frades A, Colino T. Selective Hypersensitivity to Boiled Razor Shell. J. Investig Allergol Clin Immunol.2007, 17(4):271-273.

16. National Research Council (1996). Guide for the Care and Use of Laboratory Animals. National Academy Press, Washington, DC.

17. Oloyede O. I. Chemical Constituents of Cowry (Cyparicasamplomoneta). Pakistan Journal of Nutrition 2008. 7 (4):540542 .

18. Rajesh Kumar S, Ishaq Ahmed V, Parameswaran V, Sudhakaran R, SarathBabu V, Sahul Hameed A. Potential use of chitosan nanoparticles for oral delivery of DNA vaccine in Asian sea bass (Latesca lcarifer) to protect from Vibrio (Listonella) anguillarum. Fish Shellfish Immunol.2008,25:47-56.

19. Singh, A., Dev Dubey, S., Patney, S. and Kumar, V. Acute and sub-chronic toxicity study of calcium Based ayurvedic 'bhasmas' and a 'pishti' Prepared from marine animals. Journal of Herbal Medicine and Toxicology 2010, 4 (1) 35-47.

20. Traniello S, Barsacchi R., Magri E and Grazi E. Molecular Characteristics of Chicken KidneyArginase. Biochem. J.1975, 145: $153-157$.

21. Usman A. "Standard Operating Procedure" National Agency for Food and Drug Administration and Control (NAFDAC) Boriki PortHacourt, Nigeria. PP 7114. Heinemann Medical Books Ltd.: New York, NY. 122, 184. 2006

22. Weber K and Osborn M. Protein and sodium dodecyl sulphate. Molecular weight determination, polyacrylamide gel and related procedures. 'In: The Proteins', 3rd edition. Edited by Newrath H and Hill R. L. Academic Press, New York. 1975, 179-223.

23. Weiner S, Lowenstam HA and Hood L. Characterization of 80-million-year-old mollusk shell proteins. Proc. Natl. Acad. Sci.1976, 73(8):2541-2545. 